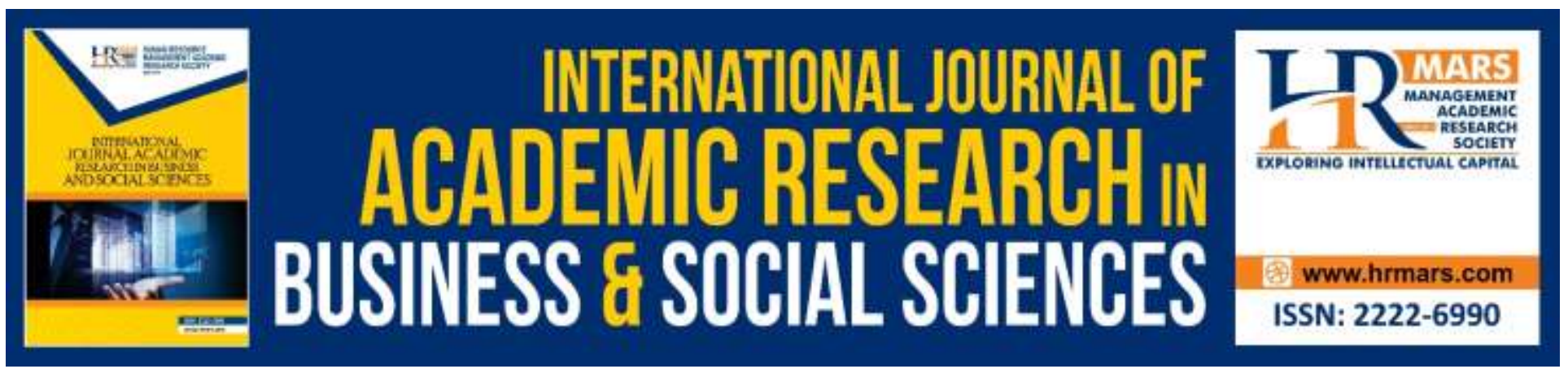

\title{
An Investigation of Blending Inculturation and Liberation approaches towards new evangelization in Contemporary Africa
}

\author{
P. N. Wachege, Steven Nduto Syengo
}

To Link this Article: http://dx.doi.org/10.6007/IJARBSS/v8-i7/4325

DOI: $\quad 10.6007 /$ IJARBSS/v8-i7/4325

Received: 24 May 2018, Revised: 19 June 2018, Accepted: 23 June 2018

Published Online: 26 July 2018

In-Text Citation: (Wachege \& Syengo, 2018)

To Cite this Article: Wachege, P. N., \& Syengo, S. N. (2018). An Investigation of Blending Inculturation and Liberation approaches towards new evangelization in Contemporary Africa. International Journal of Academic Research in Business and Social Sciences, 8(7), 72-86.

\section{Copyright: (C) 2018 The Author(s)}

Published by Human Resource Management Academic Research Society (www.hrmars.com)

This article is published under the Creative Commons Attribution (CC BY 4.0) license. Anyone may reproduce, distribute, translate and create derivative works of this article (for both commercial and non-commercial purposes), subject to full attribution to the original publication and authors. The full terms of this license may be seen

at: http://creativecommons.org/licences/by/4.0/legalcode

Vol. 8, No. 7, July 2018, Pg. $72-86$

Full Terms \& Conditions of access and use can be found at http://hrmars.com/index.php/pages/detail/publication-ethics 


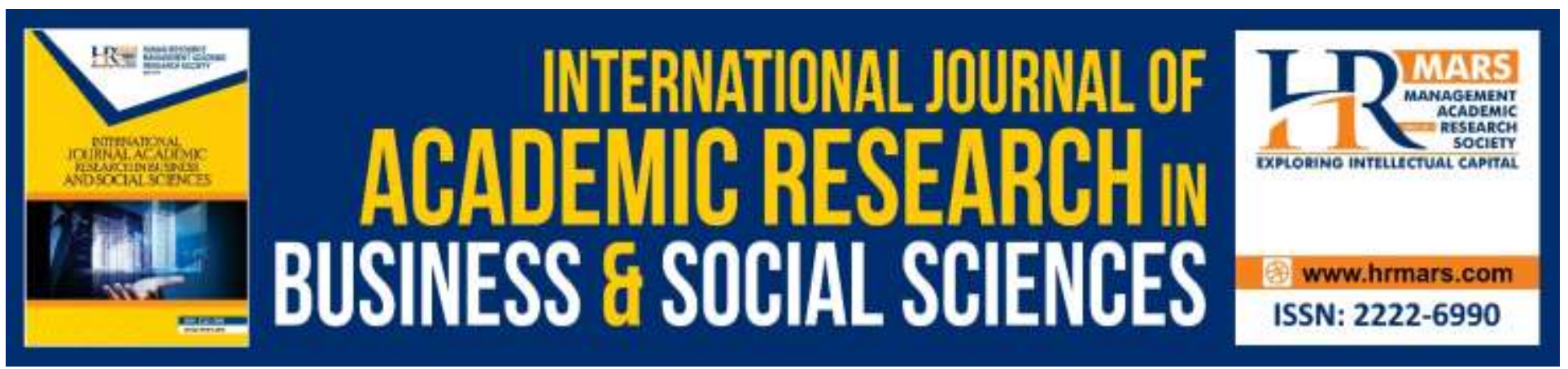

\title{
An Investigation of Blending Inculturation and Liberation approaches towards new evangelization in Contemporary Africa
}

\author{
Prof. P. N. Wachege \\ Department of Philosophy and Religious Studies, University of Nairobi, Kenya \\ Nairobi, Kenya \\ Email: patricknwachege@gmail.com \\ Steven Nduto Syengo \\ PhD Candidate, Department of Philosophy and Religious Studies, University of Nairobi, Kenya \\ Nairobi, Kenya \\ Email: stevennduto@gmail.com
}

\begin{abstract}
In the endeavour towards propagating the Good News, there seems to be a dangerous categorization of Inculturation and liberation approaches as if they are dichotomized entities that impacts negatively on Christianity's Kerygma (proclamation) and Didache (catechesis). The paper assumes that an intrinsic combination of these two main approaches would result in a holistic mode of evangelization that would fruitfully inspire and significantly empower contemporary people in Africa to embrace the Gospel in their entire concrete existence while taking them separately would result in impoverished ministry. One may thus hypothesize that a merger of the two approaches would greatly influence the way agents of the Gospel accomplish Christ's mandate to effectively propagate Christianity, in corroboration with the Holy Spirit, in Jerusalem, Judea, Samaria and to the remotest parts of the world (Acts 1:8), including today's Africa. Such an assertion merits investigation at erudition level since it has been either ignored or handled superficially. Going by the assumption that Inculturation approach and liberation perspective in significant ministering of the Gospel have an indispensable affinity and actually, not just factually, necessarily imply one another (Nyamiti, 2005:3-5) the study endeavours to verify that the merger has the potentiality of bringing about a holistic more effective evangelization mode that would bear abundant fruits in Africa in accordance with respective people's socio-religio-cultural realities and signs of the times. Based on the above, the study will be guided by questions like: What is the perception and engagement of Inculturation approach in evangelizing service? How does the Christian Church understand and utilize liberation approach in the role of evangelization? How does the merger of Inculturation and liberation approaches make evangelization more significant in contemporary Africa? In what manner can the integrated model in Christian ministry be applied by the contemporary agents of evangelization in Africa to maximize the
\end{abstract}


INTERNATIONAL JOURNAL OF ACADEMIC RESEARCH IN BUSINESS AND SOCIAL SCIENCES Vol. 8, No. 7, July 2018, E-ISSN: 2222-6990 @ 2018 HRMARS

benefit to contemporary recipients in their historical concrete life situations? The paper will thus give a brief historical theological setting on the subject then scrutinize the nature and engagement of Inculturation approach in the evangelization ministry. It will also explore the perception and employment of liberation approach towards evangelization endeavour. This will be followed by a brief discussion on the blending of Inculturation and liberation orientations as a more fruitful mode of evangelization. Inculturation theory together with general and special revelation theory will guide the study.

Keywords: Inculturation, Liberation, Blended Inculturation and liberation Approaches, Second/New Evangelization, Conscientization, and Christian Faithful.

The paper will follow the following sequence: It will commence with some introductory reflections accompanied with explanation and operatinalizing of the above key concepts. After that it will examine the two interrelated theories that guided the study. This will be followed by a brief historical theological setting of the subject. It will then elaborate Inculturation approach. The next step is that of explicating liberation approach. A discussion on blending Inculturation approach and liberation approach will follow. The paper will then end with the study's implications, recommendations and conclusion together with references.

\section{Introductory Reflections}

Christianity, by its very essence, is supposed to address the recipients in their totality which demands employment of commensurate harmonized methods of understanding, delivery and application in concrete living within the context of situations in life. In the endeavor, Church history discloses that the outstanding methods of delivery in evangelizing include Inculturation approach which is the interaction between Christianity and the diverse cultures of those upon whom it is propagated (Shorter, 1988:8). The other one is liberation approach which means a theological moment of the experience of Christian faith when it undertakes to consciously transform a world in a situation of dependence on the basis of the Gospel (Boff, 1980:1). A combination of these two main approaches, which is the main goal of the paper, may be said to result in a holistic mode of evangelization that would fruitfully inspire and empower contemporary Africans in their restlessness, existential worries, concerns, challenging striving towards fulfillment of their potentialities in demanding ideals and socio-cultural religious and political identities (Wachege, 1992:43-56; Martey, 1993:1ff). In such a scenario, one would assume that such Inculturation and liberation approaches would have a vivid impact on the relevance and worth of what the agents of the Gospel are chosen and mandated by Jesus Christ to accomplish among their flock (Mt 28:19-20). A related narrative is that inadequate or no effort in integrating the twofold fundamental orientations would result in a lacuna in ministry towards today's Africans. It would impoverish the significance of evangelizing transforming results of the Gospel in people's socio-religio-cultural, economic, political and other existential realms relevant also to the recipients' situations in life, changing generations and signs of the times. These factors are no doubt in need of new evangelization which, more so in Africa, remains a timeless reflection of Christ's mandate, message, and mission entrusted to His Church in the world (Acts 1:8; Mt 28: 19-20; Mk 16:16-18). In Matthew 28:19-20, Jesus sends out his disciples saying: "Therefore go and make disciples of all nations, baptizing them in the name of the Father and of the Son and of the Holy Spirit, and teaching them to obey everything I have commanded you. And surely I am with you always, to the very end of the age." This passage and message, with its renounceable priority in 
INTERNATIONAL JOURNAL OF ACADEMIC RESEARCH IN BUSINESS AND SOCIAL SCIENCES Vol. 8, No. 7, July 2018, E-ISSN: 2222-6990 @ 2018 HRMARS

preaching the Gospel (Haring, 1979: 15) has to be pragmatically demonstrated by the agents of the Gospel.

At this stage, the reader needs to be clear of the key concepts the paper utilizes and how they are operationized to be better persuaded concerning the paper's motivation and contribution. The common understanding of the term Inculturation is that of confronting Christianity with diverse cultures. In the study, which is mainly theological, the term will be used to mean "the insertion of the tradition of Christian faith into a non-Christian culture and a subsequent ongoing dialogue between that faith and the culture into which it is inserted" (Shorter, 2005: 17). The concept Liberation Theology is operationalized to mean a theological moment of the experience of Christian faith when it undertakes to consciously transform a world in a situation of depended on the basis of the Gospel (Boff, 1982: 1). In the study, the concept Blended Inculturation and liberation approaches will mean the merging or intertwining of liberation orientation and Inculturation perspective in theologizing and evangelizing endeavour. It will also be utilized as a way of doing liberation theology whereby Inculturation is taken as a point of departure for the theology of liberation since the two orientations are essentially related though not equated (Wachege, 2018:357-358). Second Evangelization, a correlative of New Evangelization, reflects the advanced conditions in which evangelization is carried on in the contemporary world amongst people that were evangelized before but are now living in intolerant world that contradicts and even hinders the Gospel (Carrier, 1994). We then have the term conscientization

which is operationalized to convey creation of awareness thereby assisting in learning to perceive social, political and economic contradictions and to take action against the oppressive elements of reality (Freire, 1998: 41ff). Our final key concept is Christian faithful. These are the disciples and followers of Jesus Christ who, out of loyalty to Him, are guided and identified with his principles letting Christ's standards reign upon them. The study thus uses the term to mean: "Those who, inasmuch as they have been incorporated in Christ through Baptism, have been constituted as the people of God; for this reason, since they have become sharers in Christ's priestly, prophetic and royal office in their own manner, they are called to exercise the mission which God has entrusted to the Church to fulfill in the world, in accord with the condition proper to each one (Pope John Paul 11, 1992: no. 871). The above introductory reflections lead us to the theories the paper utilized.

\section{Theories that Guided the Paper}

The study was guided by two theories namely: Inculturation theory together with general and special revelation theory briefly elaborated bellow.

In the light of Ad Gentes Article 22 (Flannery, 1975: 839-840), Pope John Paul 11 enriches the study with the theory of Inculturation. He creates awareness that every culture has godly elements that ought to be creatively explored and exploited in explaining and propagating the Gospel in Christic mandate of inclusive missionary enterprise utilizing appropriate approaches relevant and significant for new evangelization. Such an endeavor is called Inculturation. He does not stop here but goes on to explain that, owing to evil among people, every culture, though God-given, is distorted and polluted by characteristics that are incompatible with Christianity thus needing a process of separating them from the valuable qualities to be employed for the above evangelization ministry. Such an undertaking is called liberation which scrutinizes and polishes the respective cultures so as to draw good elements to be implemented in evangelization and discard the repugnant ones - hence the inter-dependence and affinity between Inculturation and Liberation theologies emerges. The 
INTERNATIONAL JOURNAL OF ACADEMIC RESEARCH IN BUSINESS AND SOCIAL SCIENCES Vol. 8, No. 7, July 2018, E-ISSN: 2222-6990 @ 2018 HRMARS

Pontiff articulates the above as follows: "One of the aspects of this evangelization is the Inculturation of the Gospel, the Africanisation of the Church...That is part of the indispensable efforts to incarnate the message of Christ. The Gospel, certainly is not identified with the cultures, and transcends them all, but the Kingdom that the Gospel proclaims is lived by people deeply tied to a culture" (Hickey, 1982: 258).

He goes on to underscore the liberation engagement by asserting that in the process or ministry of evangelizing: "It is important to carry out a thorough investigation of the cultural traditions of the various populations and of the philosophical ideas that underlie them in order to detect elements that are in contradiction with the Christian religion and the contributions that can enrich theological reflection" (Ibid, : 258). The above theory and other related Christian theological reflections and instructions may rightly be said to have inspired the study to investigate the merger of Inculturation and liberation approaches to the ministry especially to the contemporary Africans that would contribute to the required new evangelization.

General cum special revelation theory is propagated by scholars like Latourelle where he explicates the issue of "external and internal testimony" guided, empowered and inspired by the Holy Spirit who also appropriately disposes the recipients to welcome and own the Christian message delivered to them (Latourelle, 1966: 383ff). Rahner makes it more explicit by explaining that owing to theocentricity involved in creation, God freely makes Himself and His plan of salvation known to people in their humanness, concrete historical existence and environs. But God, furthermore, owing to Christocentricity, discloses Self and His will in the best way possible and most explicitly through Jesus Christ in His historical concrete existence, redemption instructions together with salvific teachings (Rahner, 1978: 144- 161).

Dupuis makes it even clearer by focusing on the twofold perspectives of revelation within the umbrella of redemption and salvation explaining God as revealing Self through creation, in God's capacity as the Creator, to all such that all are enabled to know God and His economy of salvation through what the Almighty endows them with which includes their socio-religio-cultural elements; and God's disclosure in the best way possible through Jesus Christ as special revelation (Dupuis, 1997: 29-52; 217-227). The theory will assists the work in exploring how today's evangelizers should draw from such a principle in diversifying and blending modes of ministry particularly in African of today geared towards new evangelization. It is worthy, therefore, to locate the issue of research in a brief historical theological base.

\section{Historical Theological setting of the Subject}

In this sub-title, the paper reviews resourceful works by the following scholars: Baur, Pope John Paul II, Congar, Dupuis, Kato, and Pope Francis. We are aware that there are many more related works which could be included. Among them are those by Mveng, Mushete, Tshibangu, Uzukwu, Adoukonou and Bimwenyi (Bujo and Muya, 2003). Nevertheless, owing to the limitation imposed in the paper settled for the aforementioned as adequate.

Baur, in his classic monograph, 2000 years of Christianity in Africa: An African History (62-1992) (Baur, 1998), presents a comprehensive historical theological treatise on early missionary agencies and evangelization in the whole of Africa and their diversified strategies of propagating the Gospel (Ibid, :258). Both as a missionary from Switzerland and a scholar who taught for over 40 years in Major Seminaries like St. Thomas Aquinas in Nairobi Kenya, Peramiho in Tanzania and Tindinyo in Kenya since 1956 he was well equipped for the above task. He was so at home in Africa that he chose to spend his retirement in Africa until his death. Baur provides a monumental work on the first 
INTERNATIONAL JOURNAL OF ACADEMIC RESEARCH IN BUSINESS AND SOCIAL SCIENCES Vol. 8, No. 7, July 2018, E-ISSN: 2222-6990 @ 2018 HRMARS

encounter of Africa with Christianity in the Northern Africa from AD 62-1500 (Ibid, : 21-42); the second encounter of Africa with the Gospel in the Ancient African kingdoms from 1400-1800 (Ibid, :43-99); The third encounter of Africa with the Gospel as foundation of Modern Christianity from 1792-1918 (Ibid, : 103-260); and then handles Twentieth Century Christianity using a country by country survey (Ibid, :263-518). The author documents an expansive and general record of the early missionary strategies for evangelization in Kenya without particularly settling on any specific contextual analysis for comprehensive details as the paper does.

Pope John Paul 11 had the reputation of being not only the second longest serving Pontiff in history but also the one who made the greatest number of global missionary journeys - three of them here in Kenya. What is of greatest significance for the study is that Inculturation was dear to him as he gave invaluable insights relevant to this study. In his Address to the Bishops of Zaire (today's DRC) and the whole of Africa the Pontiff did not only instruct on the duty and obligation of the African Christians in evangelizing endeavor to make Christianity "truly African" but to also investigate the mutual enrichment between the African socio-religio-cultural endowments and Christianity while guarding from parochial mindedness or false particularism and syncretism (Hickey, 1982:258ff). He also provides Inculturation theory which guides the study creating awareness that all cultures are God-given which ought to be used to explain Christian doctrines according to the needs, aspirations, thought-forms and mentality thus making the respective doctrines beneficial to diverse people and changing generations with the sensitivity of the signs of the time (Ibid, : 259ff). He further accentuates the indispensability of Inculturation as an essential requisite of propagating the Good News. He says: "One of the aspects of this evangelization is the Inculturation of the Gospel, the Africanisation of the Church. That is part of the indispensable efforts to incarnate the message of Christ since the Kingdom that the Gospel proclaims is lived by man deeply tied to a culture" (Ibid, : 258). The Pontiff's reflections based on Vatican 11 article namely Ad Gentes Article 22 and his own reflections together with sourcing from other theologians' ideas triggering the theory of Inculturation add value to the work.

The magisterial document, Ad Gentes, Article 22 conscientices us that: "The seed which is the Word of God grows out of the good soil watered by the divine dew, it absorbs moisture, transforms it, and makes it part of itself, so that eventually it bears much fruit. So too indeed, just as happened in the economy of the Incarnation, the young Churches, which are rooted in Christ and built on the foundations of the Apostles, take over all the riches of the nations which have been given to Christ as an inheritance (Ps 2:8). They borrow from the customs, traditions, wisdom, teachings, arts and sciences of their people everything which could be used to praise the glory of the Creator, manifest the grace of the Savior, or contribute to the right ordering of Christian life" (Flannery, 1984:839). Brechter's clarifies the issue further saying: "Vatican 11 has recognized the legitimacy of pluralism in the Church and made adaptation a programme. Since the Kingdom of Christ is not of this world (Jn 18:36), the Church or the People of God takes nothing away from the temporal welfare of any people by establishing that Kingdom. Rather does She foster and take Herself in so far as they are good, the ability, resources and customs of each people" (Brechter, 1969: 150-151). The documents, moreover, spell out that every single culture, including the African ones, have their potential contribution to Christianity and ought to be exploited critically to draw values which should be prudently utilized in understanding, elaborating and propagating the Good News thereby implying a double pronged approach namely Inculturational and liberational towards evangelizing (Flannery,1975:256ff). The scenario demands a meaningful significant evangelization which employs theological investigations in each major socio-ethical cultural area (Ibid, : 256). This is how the theory of Inculturation is 
INTERNATIONAL JOURNAL OF ACADEMIC RESEARCH IN BUSINESS AND SOCIAL SCIENCES

Vol. 8, No. 7, July 2018, E-ISSN: 2222-6990 @ 2018 HRMARS

concretized by the Pontiff. He, nevertheless, is not as elaborate in the application of these good ideas as the paper does.

While the above contribution is so invaluable especially with regard to Inculturation orientation of theologizing and evangelizing, nevertheless, the same may not be said of liberation approach which is just hinted at here.

Congar provides works on the issues relating to evangelization that requires the input of the lay people and the indispensable animation, guidance and empowerment of the Holy Spirit. He explains that, as the principle of life, the Paraclete perpetually inspires the agents of Christianity in the proclamation and catechizing roles towards living Christianity and holistically witnessing God's salvation and redemption to all seriously taking into account people's socio-religio-political and cultural endowments, needs and setting (Congar, 2010:54ff). He further popularizes the theory of special revelation which is mainly Christocentric and general disclosure which is theocentric in the light of missionary enterprise. This theory spells out that respective ethnic groups and races have own world-views which contain elements of Godliness thanks to the seeds the Creator gratuitously endow them with. The seeds should be exploited to understand, preach and live in the realm of salvation and redemption. It will amount to propagating the Gospel in a way in which the recipients will benefit from. They will do so in their historical concrete existence also imbued with godly elements that can be investigated and utilized in understanding and explaining the Good News in a manner that would be more comprehensible to the ethnic group- an exercise we call Inculturation (lbid, :55ff).

He enriches the study also by indicating that the Church does not only owe existence from Christ but she also belongs to the people and whatever is human. That is why "it will be useful to look at the Church from each of two related points of view: (1) as God's people, the community of Christians, she represents mankind toward Christ; (2) as institution, or Sacrament of salvation, she represents Christ toward the world" (Ibid, :60). The stance enables Congar to affirm that: "two mediations are joined in the Church, one going up, or representative, the other coming down, or sacramental; and through them she is the place where Christ gives Himself to the world, and the world gives itself to Christ, the place where the two meet" (Ibid, :61). On the bases of this, Congar instructs that: "When she takes root in some human grouping, there she makes Jesus Christ present at work, that Son of God of whom Paul writes that it is God's pleasure "through Him to win back all things, whether on earth or in heaven, into union with himself, making peace with them through His blood, shed on the cross (Col.1:20)" (Ibid, :61).

As such, then, awareness is created that though the Church exists in a way for herself and as sacred thing in the world, nevertheless, she does not exist for herself since she has a mission to and a responsibility to the world (Ibid, :62-63). The enigmatic reality then is that the Church belongs to the yonder life and to terrestrial life thanks to mission of evangelizing the world in all dimensions (Ibid, :62-63)in intimate collaboration with the "ultimate activating principle" who is the Holy Spiritconceptualized as the soul of the Church (Ibid, :186-188). As the true scholar he was, Congar explicates the above deeply in his trilogy on the I Believe in the Holy Spirit (Congar, 1983: Vols. 1, 2, and 3). Moreover, rooting himself on Biblical sources, for instance John 14: 25-26; 16:12-14, the author further illumines the study even more on well articulated roles of the Holy Spirit which inspired in new evangelization relevant to today's Africa too. Those Paraclete fundamental roles are: testifying, teaching and empowering us in view of the Kingdom of heaven in solidarity with our Redeemer and Savior who left the Holy Spirit as a legacy to us (Congar, 1983:193). A gap one notices is that Congar is not explicit on the issue of non-Christian religions like African traditional religions 
INTERNATIONAL JOURNAL OF ACADEMIC RESEARCH IN BUSINESS AND SOCIAL SCIENCES

Vol. 8, No. 7, July 2018, E-ISSN: 2222-6990 @ 2018 HRMARS

which the Spiritans encountered. He is also not thorough regarding inter-religious dialogue and mode of delivery in evangelizing task. This is where Dupuis comes in handy to fill up the gap.

In his monograph namely, Christianity and the Religions: From Confrontations to Dialogue (Dupuis, 2003), Dupuis, while drawing his similitude from Jesus' attitude of respect and inclusivity towards 'foreigners' who did not belong to Israel and what he thought of their religious ideas, explains the need to demonstrate an attitude of openness and sympathy towards the others respecting and learning from their socio-religio-cultural way of life instead of condemning who they are and what they have as repugnant to Christianity (Ibid, :52). He does it by explaining that, through general revelation, even non-Christian religious traditions are endowed with characteristics that are good and have salvific values which should be explored and exploited to have a beneficial propagation and catechesis of the Good News. (Ibid, :52). As such, the author legitimizes the study' effort further towards theological methods to be applied in evangelizing today that points to not only a change from the deductive approach to an inductive one which appreciates interreligious dialogue as well as which aims at contextualizing the Gospel message (Ibid, :54) that blends the aforementioned two fundamental approaches. In a commendable manner, the author in an earlier book titled Towards a Christian Theology of Religious Pluralism (Dupuis, 1997), spells out a positive shift in Christian Churches' mentality, approach and understanding of the other religious traditions and how in God's plan these traditions could mediate salvation to their members (Ibid, :100). The rationale is that they do have within them positive salvific values which if properly retrieved and inculturated would lead to a better perception, understanding and ministering of Christianity (Ibid, :131). Despite the above enrichment for the study the shortcoming is that Dupuis does not explicitly handle the methods of evangelization and how a combination of the approaches can add value to meaningful apostolate requiring of us to seek inspirations from Kato in this regard.

Kato in his article on "Evangelization in Africa: Twelve Years After the Ecclesia in Africa" presents what he calls "Evangelization strategies for the $21^{\text {st }}$ century." In this narrative he contends that, Jesus did not use physical or political power or financial influence to attract disciples. He used his divine power to heal, give life and hope; save the helpless, dinners and the deceased (Kato, 2008:122). He listened to them and gave them time to ask Him questions, understand and internalize His teaching, driving them to individual change. He evangelized to people of all classifications and positions: The poor, rich, simple, elite, Jews, foreigners, civilians, and political leaders (Ibid, 122). He communicated at their level: He used common words, experiences, simple teaching stories and more interesting methods of expression and no pretentious specialized terminologies from remote languages. Christ's attitude was positive to life (Ibid, : 123). Such a friendly yet deep approach made evangelization fascinating to the recipients. It persuaded them to embrace the message as a springboard of happiness and joy- which Kato unfortunately left out.

In his Exhortation Evangelii Gaudium (The Joy of the Gospel) (Pope Francis, 2013), Pope Francis is emphatic on the centrality of the community and Christian family life which is not so explicit in the above works. He points out various critical challenges in today's society that call for a determined attention and blending relevant approaches as way forward. Among them is the slavish adherence upon customs and traditions without subjecting them to scrutiny in reference to contemporary society's needs and mentality while the other one is selfishness and arrogant pride. He asserts that the two are among today's main hindrances towards the welfare of Christian family life notwithstanding the current situation in life and "signs of the times" (Ibid, :no. 33). He calls for a "new evangelization" that includes both the ministerial priests (the ordained agents) and common priests 
INTERNATIONAL JOURNAL OF ACADEMIC RESEARCH IN BUSINESS AND SOCIAL SCIENCES Vol. 8, No. 7, July 2018, E-ISSN: 2222-6990 @ 2018 HRMARS

(the laity) within the framework of the community of the "Family of God" each playing own role in collaboration with the others for the welfare of genuine family life (Ibid, :nos. 33ff). Additionally, the Exhortation educates on embracing Christ's teaching of living as brothers and sisters of the same Father through different ethnic communities. (Ibid, :87-91). It further underscores liberation from useless mutual conflicts (Ibid, : nos. 98.101) and making money our gods (Ibid, :nos.55f)as it instructs on getting rid of both selfishness, pride and egocentrism that ruin the family thereby proving to be a stumbling block to actualization of fruitful family life in an atmosphere of happiness and joy (Ibid, : nos.81-83). The above principles are no doubt enriching. What is lacking, however, is the concretization. As such, the paper found a need to fill up the gap.

\section{Inculturation Approach}

So much has been done by scholar like Nyamiti, Hebga, Dickson and Jean-Marc Ela (Bujo and Muya, 2006) on the subject. For practical purposes, the current thematic sub-title limits itself by focusing on works drawn from Magesa, Wachege and Shorter.

Magesa, in his book titled Anatomy of Inculturation (Magesa, 2004) explains that Inculturation begins to happen when the Gospel is propagated in such a way that the message discovers itself in a culture, accepting the elements that reveal the face of God already present and rejecting those that do not. Inculturation has two axes, one of understanding and the other of transformation (Magesa, 2004: 23ff). Understanding takes place through the linguistics forms and worldview of the people encountering the Gospel. Transformation comes as a consequence of the former and through the power of God. It changes minds, hearts and behaviors. The author takes the idea further by highlighting Inculturation of Jesus' Good News and the process of evangelizing in Africa. In his other monograph titled What is Not Sacred: African Spirituality (Magesa, 2014:186-189) he explains the effort of proper Inculturation as leading to an intensively Christianized community that would witness transformation of the different levels of its life, laws, customs, moral values and its worldview in the light of the Gospel message (Ibid, : 187ff). As such, the ongoing task makes Christianity more meaningful to Africans assisting them in encountering contemporary challenges as opportunities for their growth. Despite the above resourcefulness, a glaring gap attracts one's attention. The author does not indicate the real nature and affinity between cultures, Inculturation, Enculturation and Acculturation. This is where Shorter chips in to play the complementary role on the issue later.

Wachege, in his book, Salvation and Being Saved: An African Socio-Religio-Philosophical Touch (Wachege, 2000), elaborates the necessity and urgency for integrated evangelization in our contemporary society. The author is categorically that, in view of the changing times and society then the evangelization mode must be transformed "thoroughly to suit new changing generations, new challenges, new diverse methodologies, new ways of living and understanding life, new perspectives and new re-reading of the Bible and Tradition and traditions." (Ibid, : 115-177). The monograph is a pointer to what integrated evangelization is about in two major ways. The first one is its indispensability. If at all the preaching of Christ and Christianity have to continue transforming and impacting humanity, then "modern and appropriate methods of evangelization must substitute the conservative stale ones" (Ibid, :166). Secondly, integrated evangelization should carefully consider and embrace a holistic inclusivity of all participants' perspectives in a complementarity way. As such, we should graft or even bud non-African ways of evangelization too into our African ways to enhance worthwhile impact of our catechesis (Ibid, :165). However, the author tackles the said subject matter in broad and general terms without a specific reference to any particular context or implementers a gap the reader is welcome to fill. 
In his book, Toward a Theology of Inculturation (Shorter,1988) Shorter, who worked for many years in Africa as a White Father missionary and a scholar in CUEA University- famous for the above two approaches- as a founding member in 1984 with a huge number of Missiological and anthropological publications is greatly resourceful. According to him, since culture is a plural scenario, it follows that a commensurate evangelization be that of Inculturation that appreciates the ecclesial multicultural reality (Ibid, : xi). The interaction between Christianity and the diverse cultures of those upon whom it is propagated is indispensable. It is worth noting that the author does not just talk of culture but takes upon himself to give its nature. He enriches our article by defining culture as what human beings share i.e. their values, customs and distinctive way of living that constitutes them as a recognizably distinctive human group or society. It is essentially a transmitted pattern of meaning embodied in symbols, a pattern capable of development and change belonging to the concept of humanness itself (Ibid, : 4-5). Shorter also distinguishes between the term Enculturation and the concept Inculturation. Though occasionally used interchangeably, he makes it clear that the latter is used within theological context while the former is utilized from sociological point of view. As such, he goes on to explain Enculturation as referring to the cultural learning process" (Ibid, :5). As for the term Inculturation, he defines it as the ongoing dialogue or encounter between faith and culture or cultures (Ibid, :11). Shorter does not stop at merely defining the concept. To his credit, he explains Acculturation as "the encounter between one culture and another or the encounter between cultures as a principle cause of cultural change and a process which is a necessary concomitant of culture itself" (Ibid, :7) . Shorter's shortcoming, however, is that the blending of the aforementioned twofold fundamental approaches is lacking - a lacuna the article will take care of latter.

\section{Liberation Approach}

Here we are quick to acknowledge that there are several authors who have published important related work. To mention just a few, we have books by Bujo, Boulaga and Sanon (Bujo and Muya, 2013). For practical purposes, only works by Moltmann, Freire, Sobrino, and Boesak are examined.

The study draws inspiration from Moltmann's views where he opens Paraclete to deeper levels as a powerful emancipating force in evangelization. In his view, "the continual assertion that God's Spirit is bound to Church, its Word and Sacraments, its authority, its institutions and ministries, impoverishes the congregations" thereby emptying the Churches, while the Spirit migrates to the spontaneous groups and personal experience" (Moltmann, 1992:2). He exposes the Holy Spirit as the liberating power of life, dynamism and the space in that the Holy Spirit not only sanctifies life but energizes it and is the broad space upon which life should be lived freely (Ibid, :178). In so doing, the author once more legitimizes the study's endeavor in tackling mode of evangelization by the agents of the Gospel with the empowerment of the Holy Spirit. A gap one notices here is that the author's focus was more on European and American countries than Africa. Moreover, he gives general guidance with no explicit focus on missionary enterprise as we do. The education part of it is missing too, a gap Freire fills up.

To fill the vacuum on pedagogy as a means of ministering effectively, Freire chips in. His book, Education for Critical Consciousness (Freire, 1994), exposes critical consciousness underlining consciousness as the impetus of cultural economic and political emancipation (Ibid, :vii). The term he coined namely, conscientisation, goes a long way in reminding us that the main role of a liberator, and in our case a missionaries of the liberating Gospel, is to create awareness of the reality of evil, be it socio-cultural-political or economic, and people's capability to overcome and live in freedom as the 
INTERNATIONAL JOURNAL OF ACADEMIC RESEARCH IN BUSINESS AND SOCIAL SCIENCES Vol. 8, No. 7, July 2018, E-ISSN: 2222-6990 @ 2018 HRMARS

founder of Christianity wants (Ibid, :70).The implication here is that of propagating a kind of education that inspires hope - a type of teaching and preaching that Freire explicates broadly in his related book called Pedagogy of Hope (Freire,1992).The monograph persuasively conscientizes educators to understand the nexus between hope and corrupt leadership of the day emphasizing that hope that does not lead to transforming action does not make useful sense resulting in desperation (Ibid, :13). Despite the important positive aspects here, a notable limitation is that it does not address the evangelizers towards the awareness that as they are involved in education as special ministry, they are already participating in a crucial ministry thus commending missionary with the passion of founding and giving Christian tradition to schools and education. Above all, the Christological aspect whereby Jesus inspires in the ministry as Liberator and Teacher do not come out well, a bridge Sobrino provides.

On liberation perception, value and engagement, Sobrino in his Jesus the Liberator: A HistoricalTheological Reading of Jesus of Nazareth (Sobrino, 2001: 1ff) features prominently. Not only does he portray Jesus as the Liberator but also accentuates the inhuman and un godly exploitations and oppressions which have been real for centuries without Christology raising its finger or providing prophetic denunciation against the vice or even educating people to free themselves and live in the kind of freedom Jesus teaches (Ibid, :3ff). He explicates further that Christology provides a way forward in the midst of all people's everyday problems as he explains the importance of liberation when adequately related to Christology. Much as the reflections are useful, the author neither handles the issue of the agents of transforming evangelization nor does he shed enough light to education as a fundamental means of integral liberation is rather general.

Boesak both as a pastor and among the pioneers of South African black power theology of liberation (Boesak, 1977) shows how to evangelize using liberation as an invaluable tool. This Study is also assisted in explaining that "the search for true and authentic human identity and liberation is also to acknowledge that one's Africanness is a God-given blessing to delight in rather than a fate to be lamented" (Ibid, : 40). His book also helps us to appreciate, be proud of our beingness and assert our African values as God-given blessings. He spells out that to search for true and authentic human identity and liberation is also to acknowledge that one's Africanness is God-given blessing to delight in rather than a fate to be lamented...African theology wishes to be no more than the reflection of African Christians in the light of the word of God, on the African situation, on African culture and traditions, on the African past and African present" (Ibid, : 40). Such insights will go a long way in investigating the missionaries' mode of ministry. While the above is enrichment to the study, a major lacuna is that the author does not propagate the interdependence between liberation perspective and liberation mode. Neither does he assist the agents of Christianity in not just grafting but intertwining the two orientations for a fruitful ministry as the study endeavors to explore.

\section{Blending Inculturation Approach and Liberation Approach}

Under the current category, it will suffice to explore Martey's, Wachege's and Frostin's inputs.

In his book titled African Theology: Inculturation and Liberation (Martey, 1993), Martey deals with the two fundamental strands with regard to African Christian theology that impact greatly in evangelizing ministry namely, Inculturation and Liberation. Of particular interest for our subject is how the author points out and explains their convergence despite the specificity involved and apparent tension between them since 1970s (Ibid, : xi). The polarity in the double-pronged approach, 
INTERNATIONAL JOURNAL OF ACADEMIC RESEARCH IN BUSINESS AND SOCIAL SCIENCES

Vol. 8, No. 7, July 2018, E-ISSN: 2222-6990 @ 2018 HRMARS

according to him, is uncalled for owing to the complementarity involved in the double main perspectives analogically as the two sides of the same involvement. The assertion is that "theological hermeneutics in Africa must necessarily have a unitary perception of Inculturation and liberation (Ibid, : xi). Such a mutual fulfillment reminds the study of the sensitivity towards implementing the double-pronged approach to ministry by harmonizing the two entities towards integrated evangelization.

The author, moreover, reminds us of the six colonial fragmentations of Africa South of the Sahara. They are: Anglophone Africa, Francophone Africa, Portuguese Africa, Belgium Africa, Spanish Africa and- by then- Apartheid Africa each with specific political-cultural movement impacting on religious thought and diversified theological perspectives (Ibid, :1). The orientations, no doubt guided modes of evangelizing ministry mandated upon the propagators of Christianity by Jesus who was both an Inculturator and the Liberator par excellence. On such a base, Martey documents that: "While in independent Africa the Negritude movement in Francophone Africa and African personality in Anglophone Africa contributed significantly to the emergence of African theology of indigenization/Inculturation, in Apartheid Africa, the Black consciousness movement contributed immensely to the emergence of Black theology of liberation" (Ibid, :1). To his credit too, the author profoundly elaborates African theologizing as Inculturation theology spelling out Africanisation as fundamentally Inculturation and exposing cases of theological tension in Africa (Ibid, :6388).Significantly, he does not stop here but goes on to explain Black theology as liberation theology arguing rather persuasively that liberation is the quest for anthropological dignity as he presents issues of theological tension (Ibid, :91-115). Nevertheless, his effort to merge the two approaches (Ibid, :121-137) does not come out clearly. It is here that the study resorts to Wachege's contribution to the subject matter.

In his book titled Jesus Christ Inculturated into Agĩkũyũ Elderhood as Mũthamaki (Ideal Elder) (Wachege, 2018:357ff) Wachege suggests a blending of liberation approach and Inculturation perspective in theologizing and evangelizing endeavor. He proposes an innovative mode of doing liberation theology whereby Inculturation is taken as a point of departure for the theology of liberation since the two approaches are essentially related (Wachege, 1992:185-193). To acquire the intended goal it is not enough to do the theology of Inculturation since - according to the author each such theology is liberation, but one must have the explicit intention of taking such an Inculturational perspective as a point of departure for the theology of liberation from socio-cultural religio-economic and political dehumanization. The study learns that such an approach is both more enriching and profound than the one taken by some other liberationists. Wachege concretizes the above blended outlook in a published article titled "African Inculturation Liberation Theology" as a model of an "inculturated-liberation theology" (Wachege, 1992:43-56) using Christology as one of the main Christian mysteries for practical purposes. Despite such a rich exposition, the gap in the above is that of missing actual categories of oppression.

Frostin fills up the gap in his book titled Liberation Theology in Tanzania and South Africa (Frostin, 1988). He enriches the work by providing a summary of different levels of oppression which evangelizers are supposed to tackle so as to have an integrated approach to ministry. The invaluable complex levels of oppression and exploitation are cultural (dominant-dominated cultures), economic (rich-poor), and sexist (male-female) (Ibid, :8). We also have classist (capitalists-proletariat), ethnic (white-black), and geographic (North-South) (Ibid, :8). Based on the analysis, the author explains the intrinsic link between these factors as he points out the importance of handling them not from either 
INTERNATIONAL JOURNAL OF ACADEMIC RESEARCH IN BUSINESS AND SOCIAL SCIENCES

Vol. 8, No. 7, July 2018, E-ISSN: 2222-6990 @ 2018 HRMARS

liberation perspective or Inculturation aspect but from both approaches (Ibid, :9ff.). Nevertheless, Frostin does not spell out the consequences of his admittedly invaluable analysis. The paper thus chips in to fill up the lacuna.

\section{Study Implications, Recommendations and Conclusion}

The following implications, recommendations and conclusion are drawn from the paper which could be usefully explored by ordained ministers, lay people and academics to help come up with a new more meaningful evangelization to contemporary Africans. This will be articulated bearing in mind the major finding that there is a vivid tendency towards separating Inculturation approach from liberation approach and vice versa. This was noted from the previous reviewed works authored by scholars like Magesa, Shorter, Moltmann, Sobrino, Freire and Boesak. The implications and recommendations are also drawn from another major finding emerging from the previously reviewed works authored by Martey and Wachege that an intrinsic combination of these two main approaches would result in a holistic mode of evangelization that would fruitfully inspire and significantly empower contemporary people in Africa to embrace the Gospel in their entire concrete existence while taking them separately would result in impoverished ministry.

\section{Study Implications}

Awareness was created that although there are diverse approaches to ministry, and it is a healthy thing, two of them stand out. We indicated and elaborated that the two profound ones are Inculturation approach and liberation approach which when properly and critically blended will go a long way in making new evangelization towards a more fruitful ministry among the contemporary Africans a reality. In the light of the above, the article thus comes up with the following mode of doing liberation theology which blends liberation and Inculturation approaches critical in new evangelization to contemporary Africa as below:

1) For the theologian who intends to construct a liberation from socio-economic and political oppression, one must start from the global culture and social situation of the country or society in which such oppression is found.

2) One must then elaborate a theology which strives to liberate the oppression starting from the global cultural and social situation with which the socio-economic and political elements are closely linked.

\section{Recommendations and Conclusion}

Drawing from the insights gained in the paper, the above merger of the two approaches namely, Inculturation and liberation should be taken with the seriousness it deserves as viable towards the realization of new evangelization in today's Africa that is more significant and in accordance with the signs of the times and generation diversity. Among the expected beneficiaries are theologians who are in Inculturation fix and those who confine their theologizing to liberation approach. The conviction is that the paper's recommendations below will go a long way in minimizing the dichotomy between the aforementioned approaches thereby enhancing inclusivity of the approaches resulting in a more beneficial integrated orientation towards Christian mysteries and respective people's socioreligio-cultural realities imbued with signs of the times. Consequently, the paper further recommends an evangelization:

1) That necessarily links the Inculturation and liberation approaches to theology and new evangelization. 
INTERNATIONAL JOURNAL OF ACADEMIC RESEARCH IN BUSINESS AND SOCIAL SCIENCES

Vol. 8, No. 7, July 2018, E-ISSN: 2222-6990 @ 2018 HRMARS

2) That attacks the evil of oppression radically i.e. from within thereby avoiding the error of segregating the problem of socio-economic and political oppression from its socio-religio- a cultural rooting.

3) That immediately leads to a theology of integral liberation and Inculturation and, as such readily avoids the danger of political reduction in theology and evangelization.

4) That disposes itself well for other emerging approaches since no approach is absolutely profound to qualify as perfect.

5) That combines friendly approaches, as the article has done with Inculturation and liberation ones, to reap better Christ's mandate of propagating the Good News from Jerusalem to Judea to Samaria and, indeed to the ends of the earth (Acts 1: 8) that includes contemporary Africa.

By way of conclusion, the paper may perhaps be commended for making a humble contribution towards a new evangelization more meaningful to contemporary Africa that merges Inculturation and liberation approaches that will have a better impact by way of explicating more meaningfully Christian mysteries and analyzing in a more useful way respective people's socio-religio-cultural realities intertwined with the signs of the times.. What has been explicated in the paper justifies the belief that the aforementioned assumption and goal thereby have been achieved. The reader is earnestly invited to complement the effort.

\section{References}

Boesak, A. A. (1977). Farewell to innocence: A Social-Ethical Study on Black Theology and Black Power. New York: Orbis Books.

Boff, L. (1980). "Christ's Liberation via Oppression: An Attempt at Theological Construction from the Standpoint of Latin America," in R. Gebellin (ed.), Frontiers of Theology in Latin America. London: SCM Press.

Bujo, B., and Muya, J. I. (eds), (2003). African Theology: The Contribution of the Pioneers Vol 1. Nairobi: Paulines Publications Africa.

Bujo, B., and Muya, J.I (eds), (2006). African Theology: The Contribution of the Pioneers Vol 2. Nairobi: Paulines Publications Africa.

Bujo, B. and Muya, J.L. (2013) (eds). African Theology: The Contribution of the Pioneers Vol 3. Nairobi: Paulines Publications Africa, 2013.

Dupuis, J. (1997). Toward a Christian Theology of Religious Pluralism. Maryknoll, New York: Orbis Books, 1997.

Flannery, A. (1975). Vatican Council 11, The Conciliar and Post Conciliar Documents. Dublin: Costello Publishing Company, Inc.

Freire, P. (1994). Education for Critical Consciousness. New York: Continuum .

Freire, P. (1992). Pedagogy of Hope: Reliving Pedagogy of the Oppressed, trans. by Robert Barr. New York: International Publishing Group.

Frostin, P. (1988). Liberation Theology in Tanzania and South Africa: A First World Interpretation. Lund: Lund University Press.

Haring, B. (1979). Free and Faithful in Christ. Great Britain: St. Paul Publications.

Hickey, R. (1982), Modern Missionary Documents and Africa. Dublin: Dominican Publications.

Latourelle, R. (1966). Theology of Revelation. New York: Society of St. Paul.

Magesa, L. (2004). Anatomy of Inculturation: Transforming the Church in Africa. Nairobi: Paulines Publications Africa.

Magesa, L. (2014). What is Not Sacred: African Spirituality. Nairobi: Acton. 
INTERNATIONAL JOURNAL OF ACADEMIC RESEARCH IN BUSINESS AND SOCIAL SCIENCES

Vol. 8, No. 7, July 2018, E-ISSN: 2222-6990 @ 2018 HRMARS

Martey, E. (1993). African Theology: Inculturation and Liberation. Maryknoll, New York: Orbis. Moltmann, J. (1992). The Spirit of Life: A Universal Affirmation. Minneapolis: Fortress Press.

Moltmann, J. (1997). The Source of Life: The Holy Spirit and the Theology of Life. London: SCM Press. Moltmann, J.(1992). The Spirit of Life: A Universal Affirmation. Minneapolis: Fortress Press, 1992.

Nyamiti, C. (2005). Studies in African Theology Vol.1 - Jesus Christ, the Ancestor of Humankind: methodological and Trinitarian Foundations Nairobi: CUEA.

Rahner, K. (1978). Foundations of Christian Faith: An Introduction to the Idea of Christianity. London: Darton, Longman \& Todd.

Shorter, A. (1988). Toward a Theology of Inculturation. London: Geoffrey Chapman.

Sobrino, J. (2001). Jesus the Liberator: A Historical-Theological Reading of Jesus of Nazareth. Translated from the Spanish by Paul Burns and Francis McDanagh, MaryKnoll, New York: Orbis Books.

Wachege, P. N. (2018). Jesus Christ Inculturated into Agĩkũyũ Elderhood as Mũthamaki (Ideal Elder): A Third Millennium Fountain of Hope, Joyful Love and Ethical Issues. Nairobi: Little Eden Publishers.

Wachege, P. N. (2000). Salvation and Being Saved: An African Socio-Religio-Philosophical Touch. Nairobi: Media Options.

Wachege, P. N. (1992). "African Inculturation Liberation Theology," in L. Namwera (ed.), African Christian Studies. Nairobi: CUEA Publications, vol. 8), no. 1, March. 